\title{
Midwifery Qualification in Selected Countries: A Rapid Review
}

\author{
Shakirah Md. Sharif ${ }^{1, *}$, Wuan Shuen Yap ${ }^{1}{ }^{1}$, Weng Hong Fun ${ }^{1}$, Ee Ling Yoon ${ }^{1}$, Nur Fadzilah Abd Razak ${ }^{1}$, \\ Sondi Sararaks ${ }^{1}$ (D) and Shaun Wen Huey Lee ${ }^{2}$ (D) \\ 1 Institute for Health Systems Research, National Institutes of Health, Ministry of Health Malaysia, \\ Shah Alam 40170, Malaysia; sereneyap07@gmail.com (W.S.Y.); fun.wh@moh.gov.my (W.H.F.); \\ eelingyoon@gmail.com (E.L.Y.); fadzilahrazak89@gmail.com (N.F.A.R.); sararaks.s@moh.gov.my (S.S.) \\ 2 School of Pharmacy, Monash University, Bandar Sunway 47500, Malaysia; shaun.lee@monash.edu \\ * Correspondence: shakirah.ms@moh.gov.my
}

Citation: Md. Sharif, S.; Yap, W.S.; Fun, W.H.; Yoon, E.L.; Abd Razak, N.F.; Sararaks, S.; Lee, S.W.H. Midwifery Qualification in Selected Countries: A Rapid Review. Nurs. Rep. 2021, 11, 859-880. https:// doi.org/10.3390/nursrep11040080

Academic Editor: Richard Gray

Received: 26 August 2021

Accepted: 11 October 2021

Published: 26 October 2021

Publisher's Note: MDPI stays neutral with regard to jurisdictional claims in published maps and institutional affiliations.

Copyright: (c) 2021 by the authors. Licensee MDPI, Basel, Switzerland. This article is an open access article distributed under the terms and conditions of the Creative Commons Attribution (CC BY) license (https:/ / creativecommons.org/licenses/by/ $4.0 /)$.

\begin{abstract}
Background: While the global maternal mortality ratio (MMR) shows a decreasing trend, there is room for improvement. Midwifery education has been under scrutiny to ensure that graduates acquire knowledge and skills relevant to the local context. Objective: To review the basic professional midwifery qualification and pre-practice requirements in countries with lower MMR compared with Malaysia. Methods: A rapid review of country-specific Ministry of Health and Midwifery Association websites and Advanced Google using standardised key words. English-language documents reporting the qualifications of midwives or other requirements to practise midwifery from countries with a lower MMR than Malaysia were included. Results: Sixty-three documents from 35 countries were included. The minimum qualification required to become a midwife was a bachelor's degree. Most countries require registration or licensing to practise, and 35.5\% have implemented preregistration national midwifery examinations. In addition, 13 countries require midwives to have nursing backgrounds. Conclusion: In countries achieving better maternal outcomes than Malaysia, midwifes often have a degree or higher qualification. As such, there is a need to reinvestigate and revise the midwifery qualification requirements in Malaysia.
\end{abstract}

Keywords: midwifery qualification; midwifery practice; rapid review

\section{Introduction}

Globally, there has been improvement in the number of maternal deaths over a span of 25 years, due to better healthcare access and improvements in quality of care [1]. Similarly, Malaysia has recorded an overall decrease in the maternal mortality rate (MMR) per 100,000 live births, which fell by $24 \%$ between 2000 and 2017, but this trend has plateaued from 2006 onwards [2]. The latest World Bank statistics in 2017 reported Malaysia's MMR at 29 per 100,000 live births [3]. Although this number is below the global target set in the Sustainable Development Goal Target 3.1, Malaysia is aiming to further lower its MMR to the single digit range, as maternal deaths are often preventable and reflect the quality of maternal care [2,4]. Areas such as effective coordination and communication among providers for pregnant women, early identification, diagnosis and treatment of women with "high risk" status could influence maternal mortality rates [5-7]. Without sufficient coverage, access and support from maternity care providers especially midwives, this possesses great barriers in preventing avoidable maternal deaths [8].

One of the established strategies is to improve access to skilled midwifery practitioners and provide adequate health facilities, especially as it could significantly reduce maternal mortality and morbidity [9]. For example, Uganda has recently upgraded its midwifery education to a Bachelor's degree, and enabled midwives to employ higher-level skills compared to their certificate-trained counterparts [10]. To strengthen health systems' responses to maternal and child health, WHO recommends workforce management with regulated care providers as well as education and core competencies that meet global 
standards [11]. These standards can be found in the Global Standards for Midwifery Education Amended 2013, which has listed the minimum expectations for a midwifery programme, focusing on education that emphasises competency as a measure of quality assurance [12].

Historically, traditional birth attendants provided midwifery care in Malaysia. Access to skilled maternal care in Malaysia was expanded with community nurses providing basic maternal and child health (MCH) services in the public system [13], where the majority of service-utilisation is seen [14]. Trained through a two-and-a-half-year course at Ministry of Health Training Institutes, they serve rural community clinics where they are forefront health care providers, or $\mathrm{MCHC}$ clinics with a team comprising registered nurses and doctors [15]. In 2018, the ratio of community nurses per capita was 1 to 1379 [16]. Although the training of new community nurses ceased in 2013 [17], community nurses are still being used to deliver maternal and child health care. Nurse-midwives with one-year post-nursing midwifery training or public health nurses also provide midwifery services at primary care level [18].

An expectant mother in Malaysia with an uncomplicated pregnancy has at least seven visits to midwives throughout the antenatal period, and two routine visits where they are seen by the doctor. At each visit to the midwife, routine blood pressure, urine screening and an antenatal check-up are carried out, from which any abnormality discovered will be referred to the doctor. Community nurses manage only uncomplicated pregnancies while nurse-midwives manage the rest, in close partnership with doctors. During the postnatal period, community nurses and nurse-midwives conduct home visits to ensure the well-being of mother and baby [19].

Shortcomings in the management of obstetric complications are postulated to be contributing factors towards maternal mortality in Malaysia [20], similar to patterns seen globally [4]. The stagnant MMR in Malaysia has raised concerns among maternal health policymakers on the competency and skills of certificate- or diploma-qualified primary care nurses in managing increasingly complex maternal cases, as they require the skills to identify early indicators of risk and refer appropriately in a timely manner. It has been acknowledged that provision of maternal care by skilled providers, "trained, educated, licensed and regulated midwives" [21], can have a profound effect on maternal outcomes. Therefore, this study aims to review the basic qualifications and other requirements to practise as a recognised midwife in countries with better MMRs than Malaysia.

\section{Materials and Methods}

A rapid document review was conducted using streamlined systematic review methods [22], and reported using the Preferred Reporting Items for Systematic Reviews and Meta-Analysis (PRISMA) guidelines [23]. The protocol was registered with Open Science Framework [24].

\subsection{Study Search}

We searched PUBMED, CINAHL, EMBASE and Health Systems Evidence for studies published between 2000 to 2019. However, due to the absence of relevant articles, two reviewers (YEL and NFAR) conducted handsearching of relevant websites and Google Advanced Search using standardised key words in March 2019 [25]. Details on the search strategy can be found in Appendix A.

\subsection{Study Inclusion}

Studies were selected if they were: (1) documents from countries with a reported MMR lower than Malaysia's based on the 2015 World Bank data (any country with MMR < 40); (2) documents from credible sources such as law documents, journal articles, articles, assessment reports, theses (doctoral), association reports, midwifery association reports, midwifery association web pages, government policies, standards, government web pages, government agencies circulars and documents; (3) documents available in English; (4) doc- 
uments on the qualifications of lawfully recognised midwives or requirements to practise. Any qualification that rendered its holder able to provide midwifery services legally, with or without the professional title of "midwife", was included.

\subsection{Study Selection, Quality Assessment and Data Extraction}

Relevant study titles were screened for eligibility independently by two reviewers (YEL, NFAR), and potentially relevant studies were retrieved. Any uncertainties during screening were discussed with a third reviewer (SMS). Data were extracted independently by two reviewers (YEL, NFAR) using a predesigned and piloted data extraction table for synthesis. Verification was conducted by the principal investigator (SMS) on 10\% of randomly selected records from each reviewer. Quality assessment using the Authority, Accuracy, Coverage, Objectivity, Date and Significance (AACODS) checklist [26] was completed by YEL and NFAR.

The review was registered in the National Medical Research Registry (NMRR-18-3421-45549) and exempted from the Medical Research Ethics Committee (KKM/NIHSEC/P19-1528 (4)).

\subsection{Analysis}

A narrative synthesis of the included documents was performed, followed by a comparison between the qualification levels of midwifery practitioners in Malaysia and those in the included countries. Additionally, we looked at other requirements to be fulfilled in order to practise as a recognised midwife in the included countries.

\section{Results}

\subsection{Overview of Included Documents}

The search identified 4204 records, with 124 derived from handsearching of websites and 4080 from Advanced Google (Figure 1). A total of 153 records were further identified and screened for eligibility, and 64 documents were included in this rapid review. The study flow is shown in Figure 1.

These 64 documents described the qualifications to practice midwifery from 35 countries (Table 1). The majority of the included information was from midwifery governing body web pages $(n=11)$ [27-37] and law documents $(n=11)$ [38-48] followed by midwifery assessment reports $(n=10)$ [49-58] and midwifery association web pages $(n=8)$ [59-66]. The rest of the documents were from published articles $(n=7)$ [67-73], government web pages $(n=7)$ [74-80], practice standards $(n=5)$ [81-85], government documents $(n=4)$ [86-89] and a doctoral thesis $(n=1)$ [90]. Quality appraisal using the AACODS checklist ranged from 4 to 6 . 
Table 1. Minimum qualification required to practise as a recognised midwife.

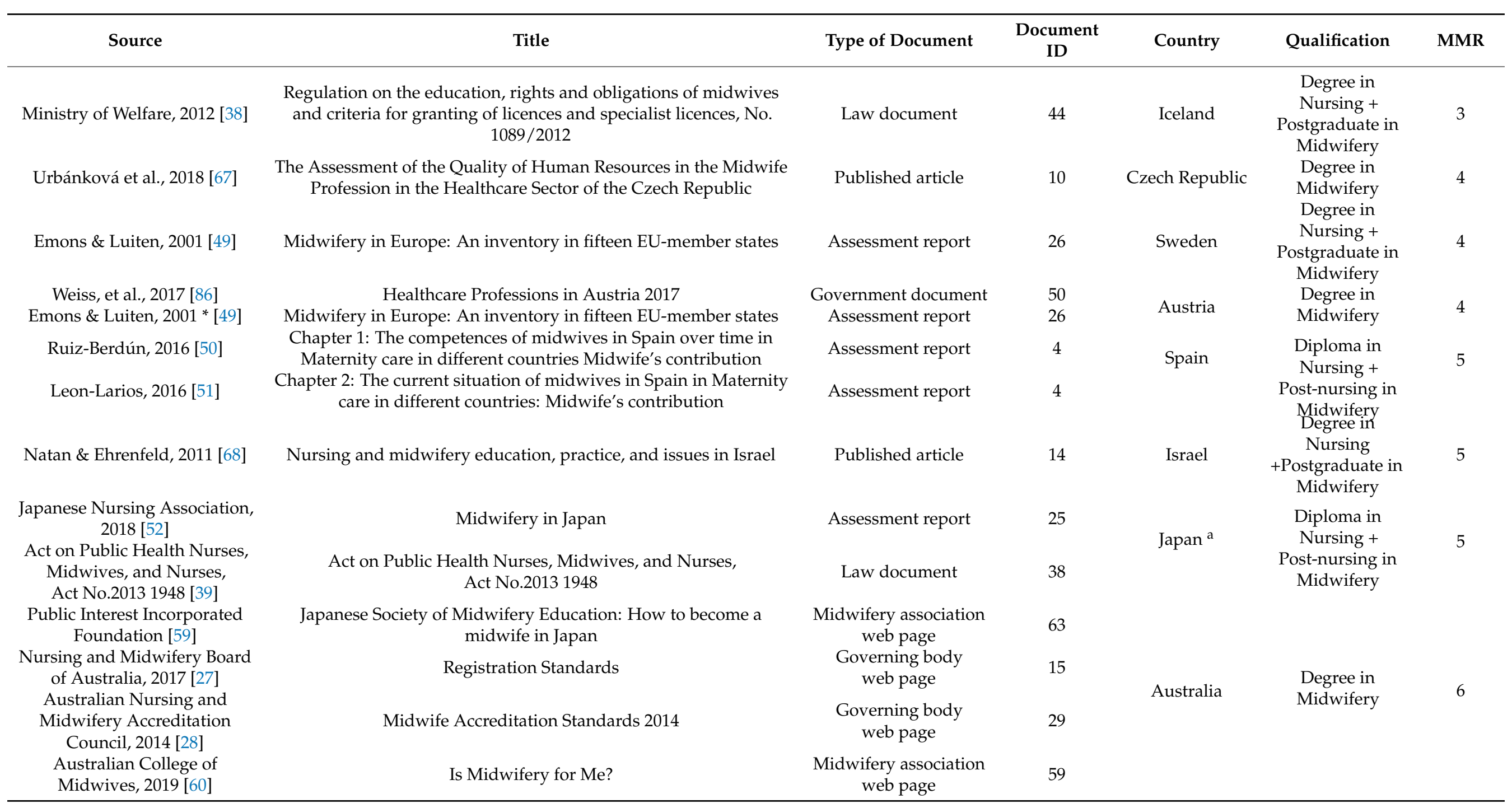


Table 1. Cont.

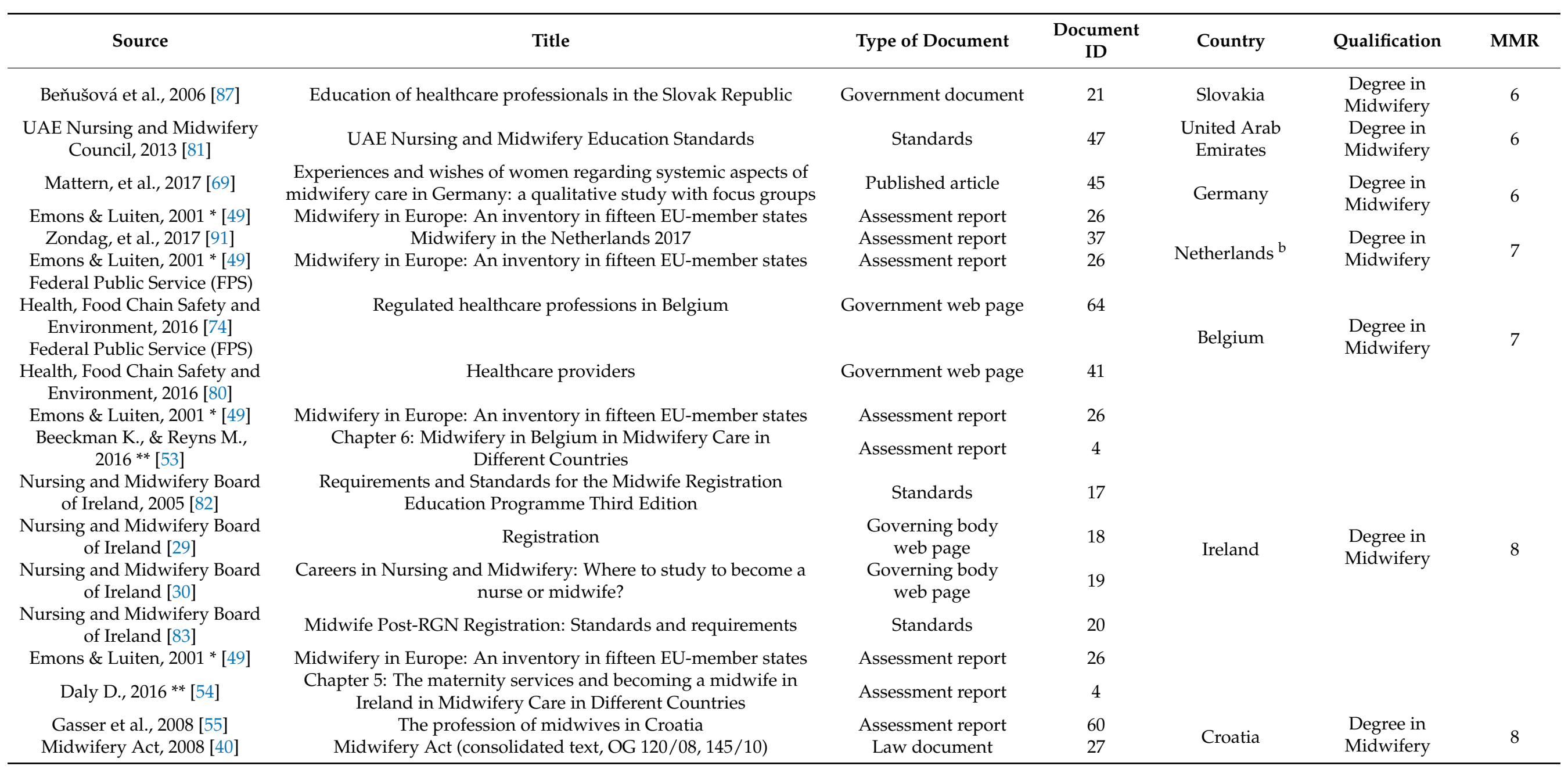


Table 1. Cont.

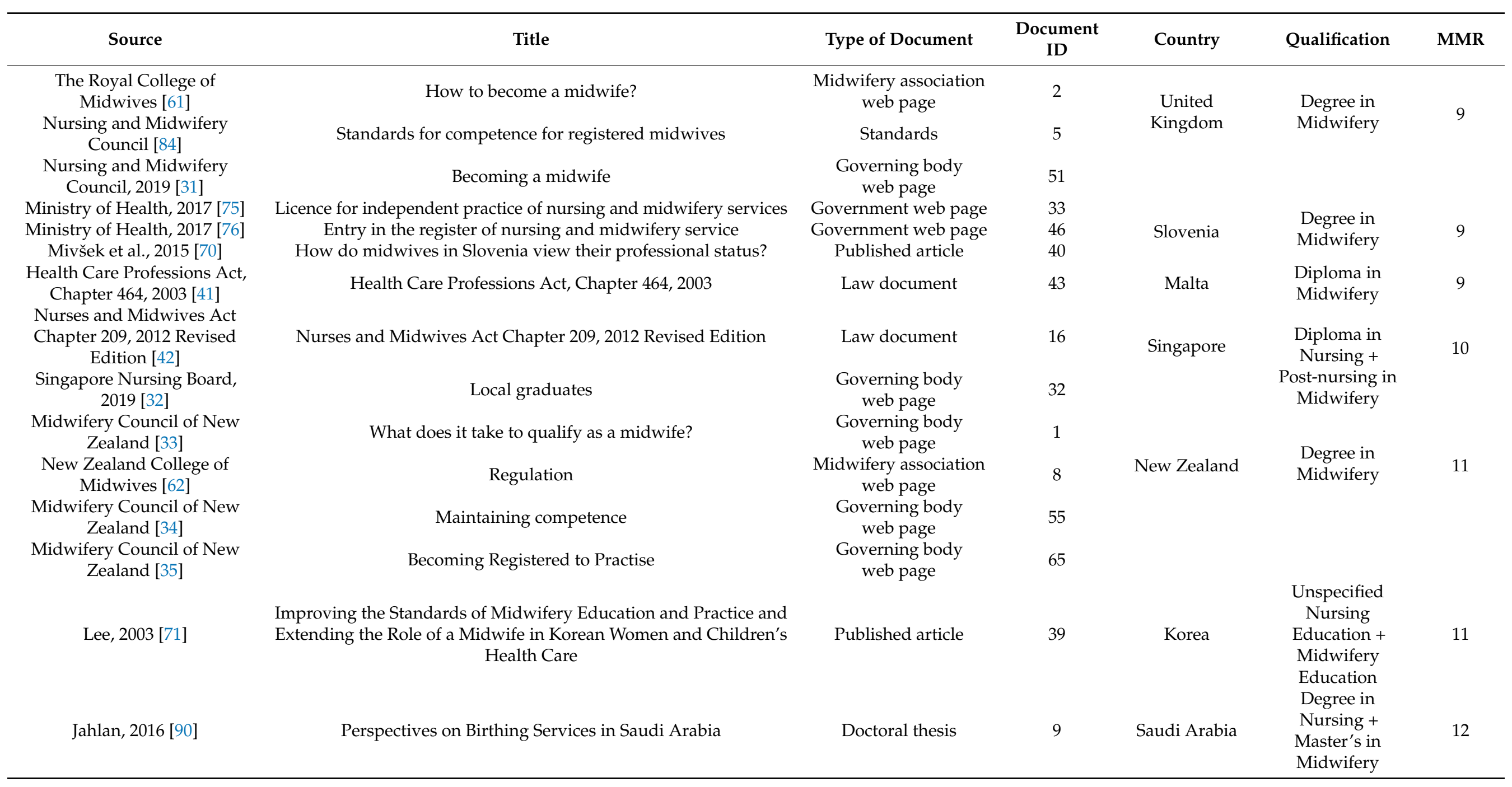


Table 1. Cont.

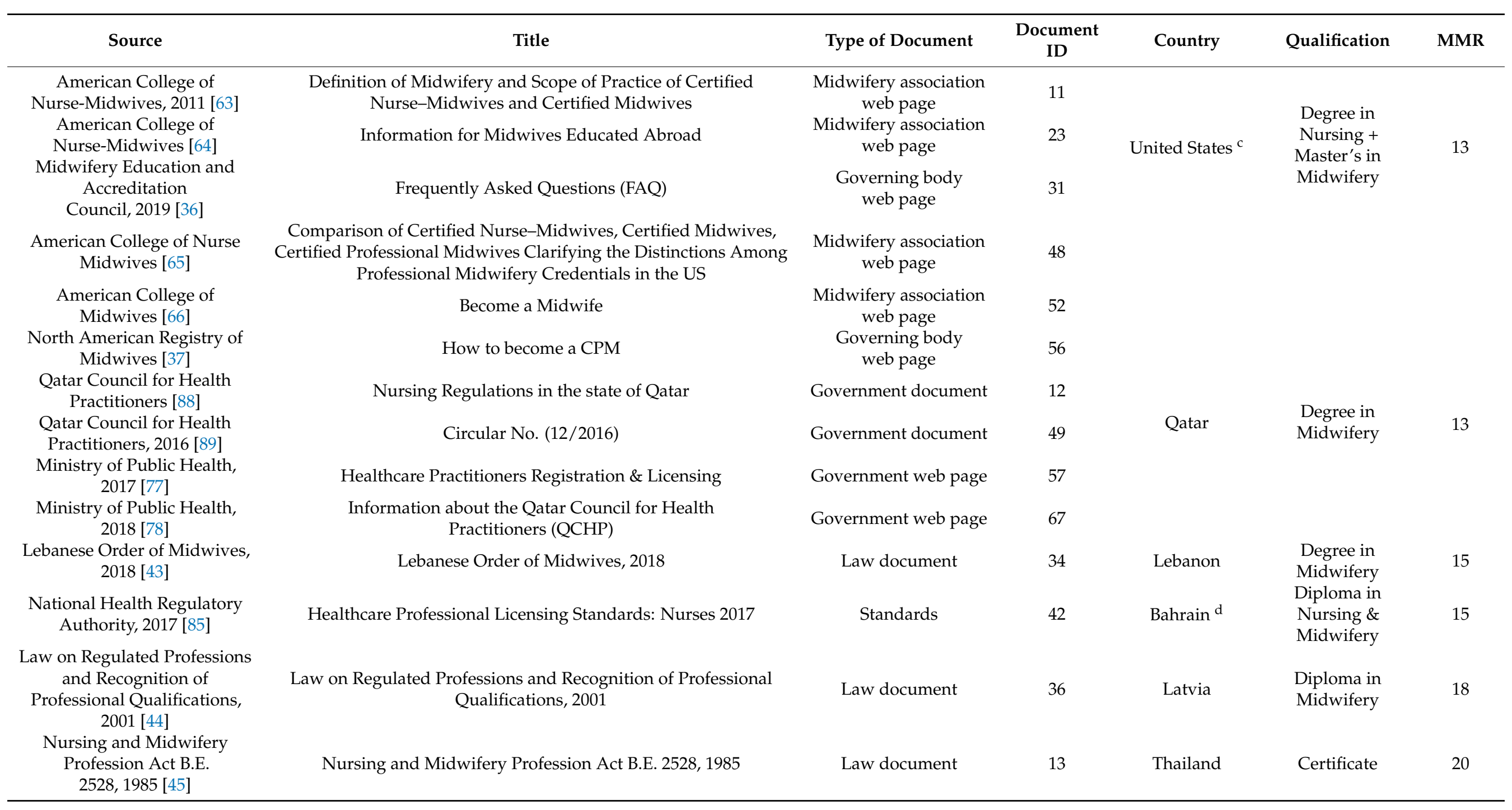


Table 1. Cont.

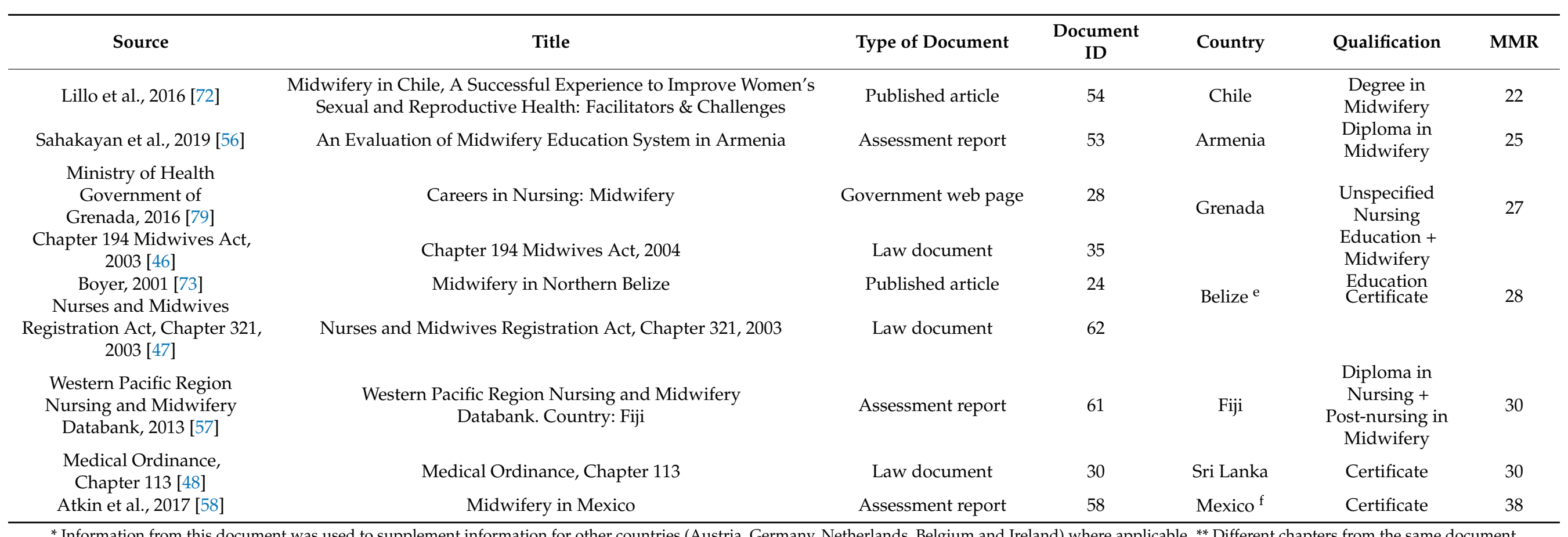

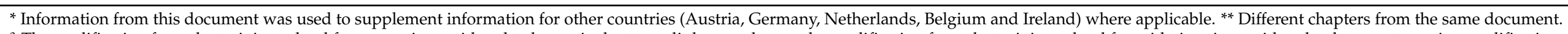

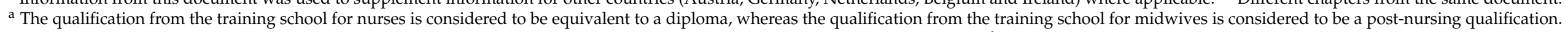

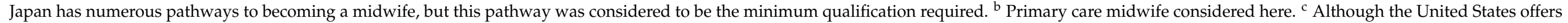

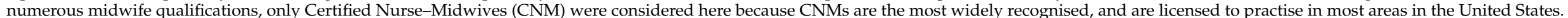

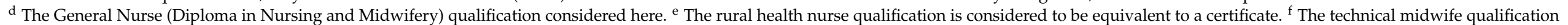
is considered to be equivalent to a certificate. 


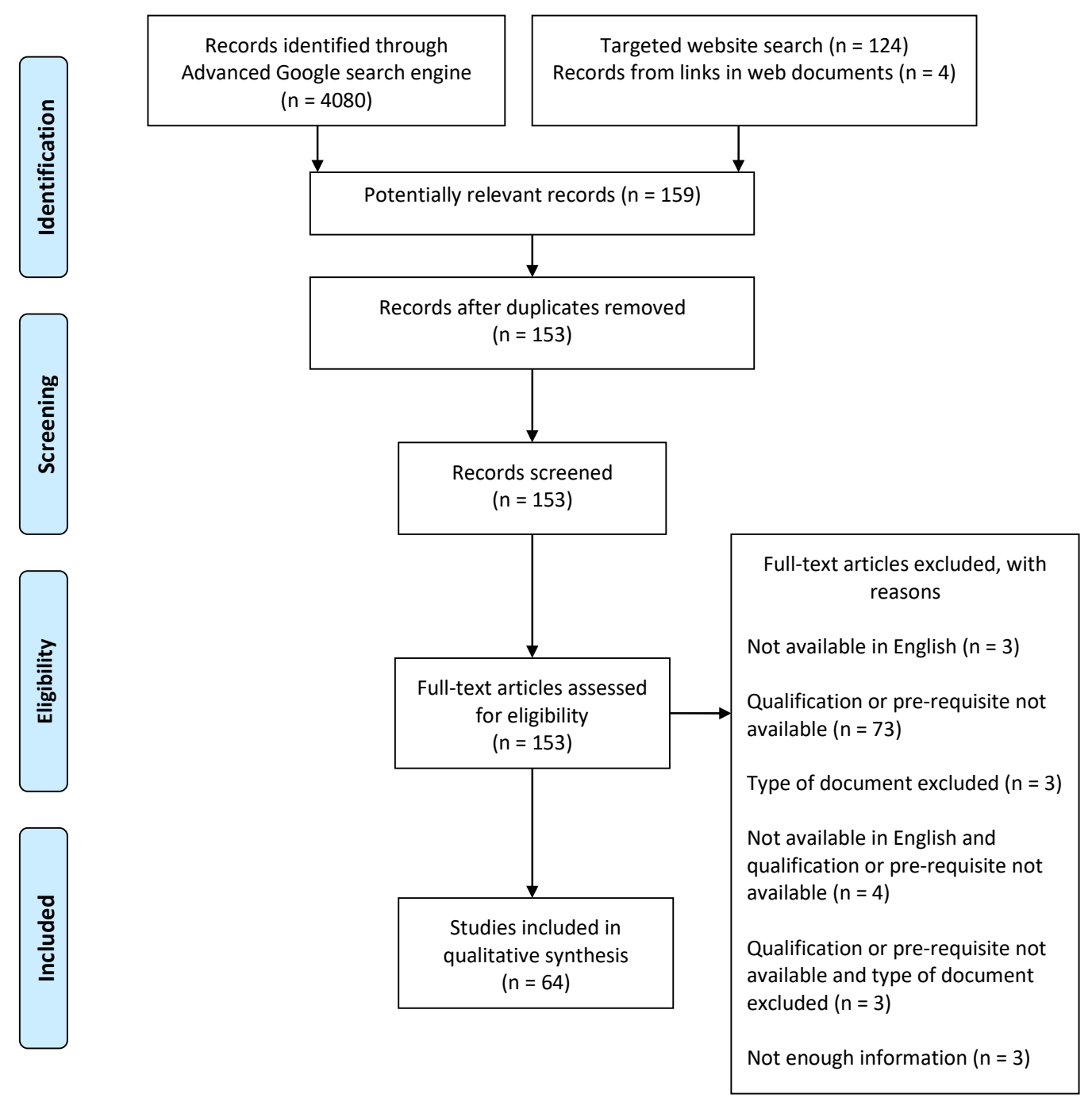

Figure 1. PRISMA flow diagram of the review.

\subsection{The Minimum Midwifery Qualification}

The minimum qualification for midwives in the included documents ranged from a certificate to a master's degree. The most common lowest qualification was a directentry degree in midwifery $(46 \%, n=16)[28,30,33,40,43,53,54,60,61,67,69,72,74,75,81,82,84$, $86,87,89,91]$. Three countries ( $9 \%$ ) required nursing degree-holders with a postgraduatelevel midwifery qualification $[38,49,68]$, whereas another two $(6 \%)$ required midwifery qualification at the master's level $[64,90]$. Similar to Malaysia, four countries $(11 \%)$ were found to require midwives to possess a diploma in nursing supplemented by a postnursing qualification in midwifery $[32,39,50,52,57,59]$, whereas another four $(11 \%)$ had certificate-level midwives (Table 1) [45,48,58,73].

Among the included countries with complete information on study duration $(n=21)$, it was observed that most direct-entry degrees $(n=10)[31,33,53,54,60,61,67,69,70,75,84,87,91]$ or diplomas $(n=3)[41,44,56]$ in midwifery were three- or four-year-long courses, whereas post-nursing $(n=3)[39,50-52,57,59]$ or postgraduate $(n=2)[49,68]$ midwifery qualifications required between seven months to two years of study (Figure 2). 


\subsection{Other Requirements to Practise as a Recognised Midwife}

Requirements other than midwifery education were not available for four countries. Of the 31 countries with available information, 28 (90.3\%) required registration and/or licensing in midwifery. Eleven (35.5\%) implemented a preregistration national midwifery examination $[33,35,39,40,42,45,47,52,55,59,62,65,68,69,71,77,78,88,89]$. Additionally, $13(41.9 \%)$ countries required midwives to have a nursing background $[32,36,38,39,46,49-$ $52,57,59,63-66,68,71,73,79,85,90]$. In addition to nursing education, seven $(22.6 \%)$ countries also required registration and/or licensing in nursing $[36,49,57,64,65,68,71,79,90]$. Only two countries $(6.5 \%)$ required new midwives to undergo supervised in-service training $[42,44]$. Table 2 summarises this information.

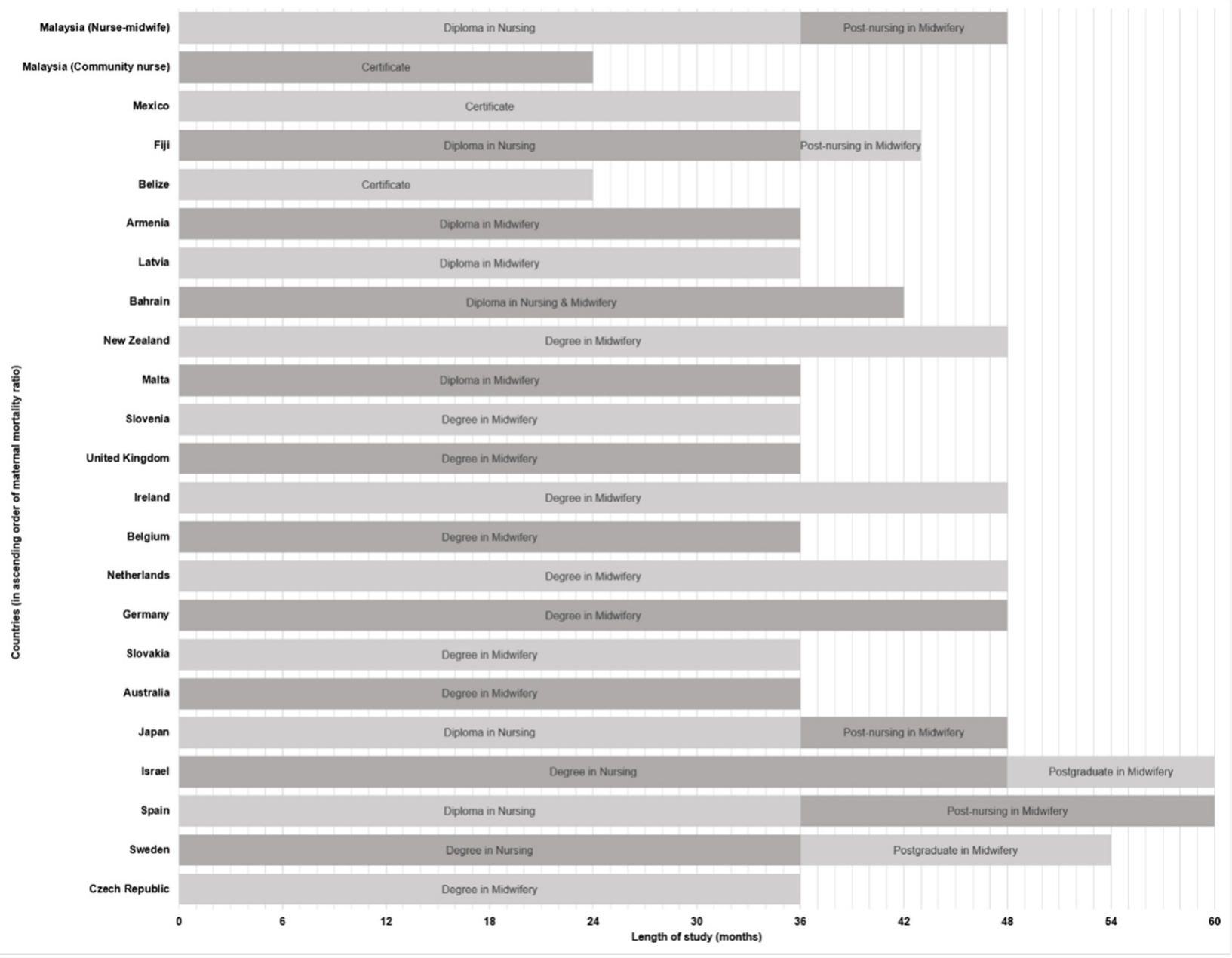

Figure 2. Study duration to become a midwife. 
Table 2. Requirements to practise as a midwife.

\begin{tabular}{|c|c|c|c|c|c|c|c|c|c|c|}
\hline \multirow[b]{2}{*}{ Country } & \multirow{2}{*}{$\begin{array}{c}\text { Maternal } \\
\text { Mortality } \\
\text { Ratio } \\
\text { (MMR) }\end{array}$} & \multicolumn{9}{|c|}{ Requirements to Practise as a Recognised Midwife * } \\
\hline & & $\begin{array}{l}\text { Nursing } \\
\text { Education }\end{array}$ & $\begin{array}{c}\text { National } \\
\text { Nursing } \\
\text { Examination }\end{array}$ & $\begin{array}{l}\text { Registration } \\
\text { as a Nurse }\end{array}$ & $\begin{array}{l}\text { Licence in } \\
\text { Nursing }\end{array}$ & Work Experience & $\begin{array}{c}\text { Supervised } \\
\text { In-Service } \\
\text { Training }\end{array}$ & $\begin{array}{c}\text { National } \\
\text { Midwifery } \\
\text { Examination }\end{array}$ & $\begin{array}{c}\text { Registration } \\
\text { as a } \\
\text { Midwife }\end{array}$ & $\begin{array}{l}\text { Licence in } \\
\text { Midwifery }\end{array}$ \\
\hline Iceland & 3 & $\bullet$ & & & & & & & & $\bullet$ \\
\hline Czech Republic & 4 & \multicolumn{9}{|c|}{ No information available } \\
\hline Sweden & 4 & • & & • & & Nurse (6 months) & & & & • \\
\hline Spain & 5 & • & & & & & & & & \\
\hline Israel & 5 & • & $\bullet$ & $\bullet$ & & & & $\bullet$ & & $\bullet$ \\
\hline Japan $^{a}$ & 5 & $\bullet$ & $\bullet$ & & & & & $\bullet$ & $\bullet$ & $\bullet$ \\
\hline Australia & 6 & & & & & & & & $\bullet$ & \\
\hline Slovakia & 6 & & & & & & & & & - \\
\hline United Arab Emirates & 6 & & & & & & & & - & • \\
\hline Netherlands ${ }^{b}$ & 7 & & & & & & & & $\bullet$ & \\
\hline Belgium & 7 & & & & & & & & - & - \\
\hline Ireland & 8 & & & & & & & & $\bullet$ & \\
\hline Croatia & 8 & & & & & & & $\bullet$ & $\bullet$ & \\
\hline United Kingdom & 9 & & & & & & & & - & \\
\hline Slovenia & 9 & & & & & & & & $\bullet$ & $\bullet$ \\
\hline Malta & 9 & & & & & & & & $\bullet$ & $\bullet$ \\
\hline Singapore & 10 & $\bullet$ & & & & & - ** & $\bullet$ & $\bullet$ & - *** \\
\hline New Zealand & 11 & & & & & & & $\bullet$ & $\bullet$ & \\
\hline Korea & 11 & $\bullet$ & & & $\bullet$ & & & $\bullet$ & & $\bullet$ \\
\hline Saudi Arabia & 12 & - & & - & & & & & • & \\
\hline
\end{tabular}


Table 2. Cont.

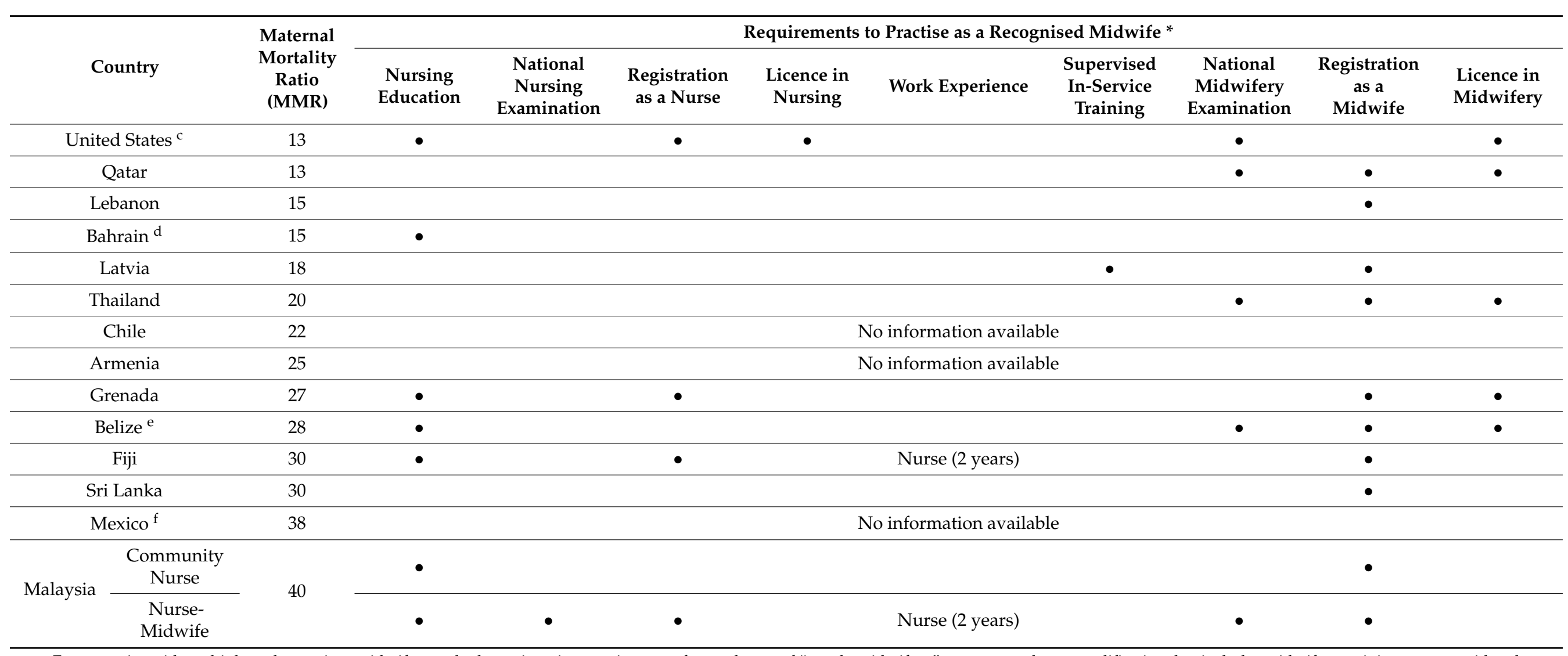

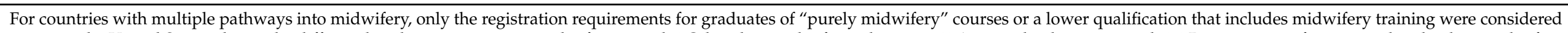

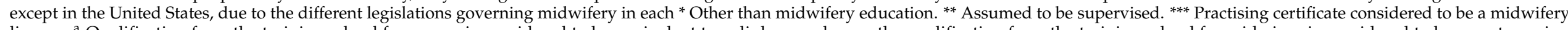

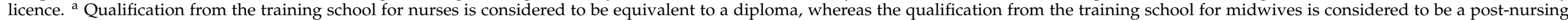

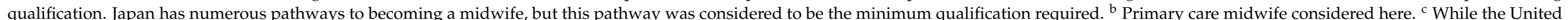

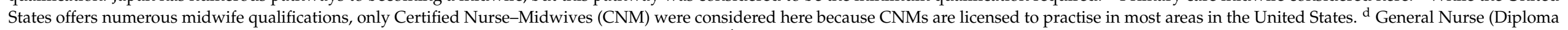
in Nursing and Midwifery) considered here. ${ }^{\mathrm{e}}$ Rural health nurse qualification considered here. ${ }^{\mathrm{f}}$ Technical midwife qualification considered here. 


\section{Discussion}

\subsection{Higher-Educated Midwives Add Value to the Practice}

Direct-entry midwifery degrees were found to be the minimum qualification in the majority of countries included. In comparison, most midwifery practitioners in Malaysia are community nurses [92] with certificate-level qualification, followed by nurses with basic qualification at certificate, diploma or degree level with a post-nursing advanced diploma in midwifery or public health [18]. The risk-approach system used in Malaysia [19] delineates case management by nurses of different qualification levels, where only low-risk cases are managed by community nurses and mild to moderate risk cases are managed by nurses.

Community nurses in Malaysia mainly serve rural clinics. While community mobilisation improves access to care, variable quality of care remains a challenge [93]. As such, WHO has called for midwives to be educated and trained to fulfil international standards, in an effort to strengthen midwifery education [94]. In Australia, recognising the need for multiskilled practitioners in the rural community, a four-year double degree programme combining nursing and midwifery was introduced in 2008 [95]. Iceland, with an MMR of three per 100,000 population in 2015 [3], have nurse-midwives, where only the best nursing students are able to qualify for a seat in midwifery training [96]. Therefore, revising the minimum qualification holds the potential for improving midwifery care standards. Additionally, further education of current community nurses can be enhanced to elevate them to the level of nurse-midwives. This would enable practise of the full scope of midwifery care as spelled out in the Framework for Action Strengthening Quality Midwifery Education for Universal Health Coverage 2030 [94].

A higher-qualified nursing workforce is valued for their variety of skills from critical thinking to effective health promotion across both inpatient and outpatient settings [97]. Undergraduate nurses were found to perform better in areas of professional practice compared to their lower-educated counterparts [98]. Various studies found that increasing the proportion of degree-qualified nurses among hospital staff resulted in lower in-patient mortality rates [99-102]. In the United States, there has been a shift to encourage nurses to obtain a bachelor's degree to achieve the Institute of Medicine's recommendation for more degree-level nurses, owing to evidence of better patient outcomes with degree-level nurses [103]. Although the available literature evaluating the impact of nurses' qualification levels is hospital-focused, it can be postulated that having degree-level midwives in primary care will result in better patient outcomes. Moreover, the Chair of the Nursing and Midwifery Council in the United Kingdom highlighted the need to have degree-level education to meet increasing work demands [104].

A participant-assessed study of undergraduates and diplomates of nursing or midwifery found that undergraduates performed better in areas of cognitive ability and reflective practice ability [105]. Shin [106] evaluated critical thinking abilities of Korean senior nursing students and found that those enrolled in undergraduate programmes scored better than those in associate degree programmes. In solving complex problems, the ability to think critically is vital in enabling midwives to arrive at the best clinical decisions in a timely manner [107]. Current evidence linking critical thinking and clinical decision-making abilities in nursing is disputable, due to the uncertain validity of methods used in measuring critical thinking, but overall such evidence seems to be credible [108]. You et al. [109] highlighted that having better-qualified nurses is essential with the expansion of nurses' roles in the community and the increasing complexity-level of care. In public healthcare systems that are often challenged by finite resources, employing undergraduate nurses who are trained to be critical thinkers and problem solvers under an evidence-based curriculum is valuable, as they are able to adapt and adjust their practice accordingly [110].

Undergraduate nurses are also more likely to be educators, participate in research and incorporate best evidence into practice [111]. Evidence-based practice (EBP), "the conscientious, explicit, and judicious use of current best evidence in making decisions 
about the care of individual patients" [112] (p.71) positively impacts patient outcomes in nursing and midwifery, reduces healthcare costs and empowers nurses and midwives, resulting in the WHO Regional Office in Europe urging its Member States to encourage and develop EBP culture in nursing and midwifery [113]. An integrative review found that although EBP in midwifery is valued, implementation is still lacking [114]. Similarly, Lai et al. [115] found that nursing and allied health practitioners in several Malaysian hospitals reported less favourable attitudes towards EBP, which could possibly be due to the low confidence attributed to their diploma qualification level. This supports the need to upgrade the qualifications of all Malaysian midwives to degree level, with emphasis on evidence-based practice as a strategy to potentially improve all maternal outcomes as they often face clinical decision-making junctures in practice.

Higher education is an empowering tool for day-to-day practice in midwifery, as midwives are at the forefront of primary care and need to be not only prepared in providing consistent advice in antenatal care, but also equipped to skilfully promote family planning, a core strategy that reduces risk of maternal death [116]. Effective counselling on preconception care by nurses or midwives has the potential to assist a woman in preparing herself physically and mentally to sustain a pregnancy [117]. Women who receive preconception counselling are more inclined to improve their health behaviour [118] and lifestyle [119] before becoming pregnant. In recognition of the extensive duties expected of a competent midwife, having better-qualified midwives will facilitate quality improvement in maternal care.

The duration of study for most direct-entry midwifery qualifications is three or four years in the included countries, while the duration of post-nursing or postgraduate studies ranges between seven months to two years. In Malaysia, graduates with community nurse certificates were simultaneously trained in midwifery and basic nursing over the short span of two-and-a-half years [120]. While community nurses are only expected to provide care for low-risk pregnancies, they are required to identify signs of escalating pregnancy risk and recognise the need for referral, while failure to do so can put both mother and child in imminent danger. Hence, with increasingly complex maternal cases, it is important for community nurses to acquire adequate knowledge and skillsets to meet expanding demands. Since effective midwifery is projected to improve outcomes, [21,116] the situation in Malaysia raises questions on whether the curriculum of local midwifery programmes is comprehensive enough to produce graduates who are as competent as the midwives with longer training durations in countries with lower MMR.

\subsection{Producing Work-Ready, Quality-Assured Midwives}

A national midwifery examination and subsequent registration or licensing ensures all prospective midwives meet the same competency standards prior to practising. Malaysian midwifery students are required to pass the national midwifery examination mandated by the Midwifery Board of Malaysia (Lembaga Bidan Malaysia) to qualify for registration [121]. We found that 11 out of 31 countries with available information implemented a preregistration national midwifery examination, whereas nearly all the countries required midwives to obtain midwifery registration and/or licensing in order to practise legally.

Midwifery registration or licensing is a certification, a formal mechanism enforced to regulate quality and competency. Certification, defined as "a process by which an authorised body, either a governmental or nongovernmental organisation, evaluates and recognises either an individual or an organisation as meeting predetermined requirements or criteria", has long been accepted as a quality improvement strategy in various healthcare professions [122] (p. 3). In the Malaysian context, midwives are governed by the Midwifery Act, which requires every person practising midwifery to be registered [121]. A literature review on how nurses perceive specialty certification reported that certified nurses were more satisfied with their job, felt more empowered in their practice and had a greater sense of collaboration with other healthcare professionals. These nurses found that certification facilitated professional growth, and had proof that their abilities were on par with those of 
the practice standard [123]. Certified nurses also reported being better able to intervene and prevent adverse outcomes due to an increased ability to recognise changes in patient status [124]. In another study, it was found that surgical wards with more certified specialty nurses had a lower rate of central-line-associated bloodstream infections [125]. Certification was thought to enhance nurses' autonomy in practice and clinical expertise, consequently improving patient outcomes [123]. Additionally, certification allows the patient to trust in the abilities of the healthcare professional in managing their health [126]. Hence, certification by a regulatory body validates the professional autonomy of a midwife, consequently generating confidence among their clients.

"Learning through doing" [127] is crucial in preparing graduates for a practical profession like midwifery. This is reflected in the recommendation by the International Confederation of Midwives, where it is stated in the Global Standards for Midwifery Education that, "the midwifery curriculum should include both theory and practise elements with a minimum of $40 \%$ theory and a minimum of $50 \%$ practise" [12] (p. 6). Our search did not reveal the actual extent of practical skills and experience required of midwifery students upon completion of their studies. However, concerns pertaining to the sufficiency of clinical preparation of midwifery graduates have been voiced $[128,129]$. Graduates have described the transition from student to qualified, professional midwife as challenging [130], stressful, an unexpected reality [131] and overwhelming [132], due to a perceived lack of knowledge and experience.

Two countries (Singapore and Latvia) reported the requirement of supervised inservice training for new midwives in our study. In Malaysia, new nurses and midwives are supported via an unofficial mentor-mentee programme where the mechanics are not set, and may differ in execution $[17,133]$. In contrast, New Zealand runs a compulsory midwifery transition programme known as the "Midwifery First Year of Practice" (MYFP) programme aimed to support new midwives in building confidence as independent practitioners, using a mentor-mentee approach with continuous professional development [134] The programme has also been found to boost retention regardless of age, race, level of education or place of work [135]. A study of midwifery students in Turkey found that internships and night shift practical training were perceived to be beneficial in preparing students for professional practice [136]. Similarly, a study of Irish midwifery students who undergo a paid 36-week internship in final year found students were able to apply knowledge into real-world practice which in turn builds confidence [127]. In Norway, a comparison between midwives who had a one-year internship as part of their two-year course and midwives who did not, found that the latter felt less prepared for practice than the former [128]. Evidently, be it internships or transition programmes, supervised clinical training prepares midwifery students in becoming self-efficacious practitioners.

\subsection{Limitations}

Although strengthening midwifery education has the potential to reduce maternal mortality, there are other associated factors that must be considered in order to improve maternal outcomes.

The database search did not yield any relevant documents that related midwifery qualifications to maternal outcomes. As such, a grey literature search was carried out. Although every effort was taken to retrieve the latest country-specific documents, there may be a delay in availability of document updates online, and thus the documents may not reflect the current country practice. Some countries may label a qualification as a "diploma", but it may be equivalent to a degree or higher. Additionally, the prerequisites and duration of study for the qualification should be considered. Not all the included countries in this review had complete information, nor were we able to retrieve information from all the countries identified as having a lower MMR than Malaysia.

While some countries offered multiple pathways into midwifery, this study only looked at the minimum levels of qualification required to practise as a midwife. The proportion of midwives corresponding to different qualification levels in each country was not considered. Also, we only included government-recognised midwifery qualifications. 
Authors or relevant midwifery organisations in other countries were not contacted for further information in this review. When required, permission was sought to use information from the included documents.

This study provides a comparison between Malaysia and countries with lower MMR than Malaysia. It would also be helpful to make comparisons with countries with higher MMR in the future to gain a comprehensive comparative understanding of global midwifery education.

\section{Conclusions}

Most countries achieving better maternal mortality outcomes than Malaysia had degree-level midwives. Revision of the qualification requirements of midwives has significant potential for improving maternal care quality and hence reducing MMR. In order to produce midwives who can stand independently at the forefront of increasingly complex maternal health demands, areas for improvement in their education must continue to be identified and addressed to ensure their continuing competency and professional development meets international standards.

Author Contributions: Conceptualisation, S.M.S., W.H.F., S.S. and S.W.H.L.; methodology, S.M.S., W.H.F., S.S. and S.W.H.L.; validation, S.M.S.; formal analysis, S.M.S., W.S.Y., E.L.Y. and N.F.A.R.; investigation, S.M.S.; resources, E.L.Y. and N.F.A.R.; data curation, E.L.Y. and N.F.A.R.; writingoriginal draft preparation, S.M.S., W.S.Y. and S.S.; writing—review and editing, S.M.S., W.S.Y., W.H.F., S.S. and S.W.H.L.; visualisation, S.M.S., W.S.Y. and S.S.; supervision, S.S. and S.W.H.L.; project administration, S.M.S.; funding acquisition, S.M.S. All authors have read and agreed to the published version of the manuscript.

Funding: This investigation was carried out by the Malaysian Alliance for Embedding Rapid Reviews in Health Systems Decision Making (MAera). MAera received financial support from the Alliance for Health Policy and Systems Research for platform establishment from 2018-2020 (WHO Reference 2018/860628-1). For this project, funding was utilised for the employment of research assistants and hospitality during meetings with stakeholders. The funders had no involvement in any part of running the project or publication of outputs from the project. The Alliance is able to conduct its work thanks to the commitment and support from a variety of funders. These include their long-term core contributors from national governments and international institutions, as well as designated funding for specific projects within our current priorities. For the full list of Alliance donors, please visit: https://www.who.int/alliance-hpsr/partners/en/ (accessed on 26 January 2021).

Institutional Review Board Statement: The study was conducted according to the guidelines of the Declaration of Helsinki, was registered under the National Medical Research Register (NMRR-183421-45549) and was exempted from ethical review by the Medical Research \& Ethics Committee (MREC) as it did not involve human or animal subjects (reference letter KKM/NIHSEC/P19-1528 (4)).

Informed Consent Statement: Not applicable.

Data Availability Statement: The data presented in this study are openly available in Open Science Framework at https: / / osf.io/gzn3a (accessed on 5 August 2021).

Acknowledgments: We would like to thank the Director-General of Health Malaysia for permission to publish this report. Sincerest gratitude for the ongoing support of individuals within and outside the Ministry of Health Malaysia for their direct and indirect contributions to the MAera platform and the conduct of this project. Last but not least, thank you to the Technical Advisory Committee from Knowledge Translation Program of the Li Ka Shing Knowledge Institute, St. Michael's Hospital, Toronto, Canada and Centre for Rapid Evidence Synthesis (ACRES) Makerere University, Kampala, Uganda for their technical assistance. In this study, input on methodology was given by the Technical Advisory Committee from Knowledge Translation Program of the Li Ka Shing Knowledge Institute, St. Michael's Hospital, Toronto, Canada. Conceptualisation of the study was conducted with the input of stakeholders from the Family Health Development Division, Ministry of Health Malaysia and Nursing Division, Ministry of Health Malaysia. Methodological input was given by Khoo Ee Ming, Liew Su May, Shaun Lee Wen Huey and Chew Boon How.

Conflicts of Interest: The authors declare no conflict of interest. 


\section{Appendix A}

Search Strategy \#1: Websites.

Government-related or midwifery-organisation websites from each country (Figure A1) were browsed individually for relevant documents. For websites with search bars, documents were searched for using the key word "midwives".

Search Strategy \#2: Advanced Google.

(Name of country) midwives education OR qualification OR pathway.

(Name of country) midwives licensing OR license OR registration.

(Name of country) midwives regulation OR act OR legislation OR law.

The search strings were entered into the search bar with all these words and no applied filters. Only the first two pages of results for each search string was included for screening.

\section{Countries Included in the \\ Search}

$\begin{array}{lllll}1 & \text { Thailand } & 31 & \text { Belize } & 61 \text { Bulgaria } \\ 2 & \text { Brunei } & 32 & \text { Croatia } & 62 \text { Norway } \\ 3 & \text { Singapore } & 33 & \text { Hungary } & 63 \text { Montenegro } \\ 4 & \text { Japan } & 34 & \text { Ukraine } & 64 \text { Uruguay } \\ 5 & \text { Saudi Arabia } & 35 & \text { Sri Lanka } & 65 \text { Oman } \\ 6 & \text { Austria } & 36 & \text { Romania } & 66 \text { Moldova } \\ 7 & \text { Belgium } & 37 & \text { Grenada } & 67 \text { Iceland } \\ 8 & \text { Denmark } & 38 & \text { Lithuania } & 68 \text { Cyprus } \\ 9 & \text { Finland } & 39 & \text { Iran } & 69 \text { United Arab Emirates } \\ 10 & \text { France } & 40 & \text { Egypt } & 70 \text { Estonia } \\ 11 & \text { Germany } & 41 & \text { Costa Rica } & 71 \text { Korea } \\ 12 & \text { Greece } & 42 & \text { Tajikistan } & 72 \text { Lebanon } \\ 13 & \text { Ireland } & 43 & \text { Mexico } & 73 \text { Kazakhstan } \\ 14 & \text { Fiji } & 44 & \text { Azerbaijan } & 74 \text { Turkey } \\ 15 & \text { Luxembourg } & 45 & \text { Uzbekistan } & 75 \text { Georgia } \\ 16 & \text { Netherlands } & 46 & \text { Russian Federation } & \\ 17 & \text { Israel } & 47 & \text { Bosnia and Herzegovina } & \\ 18 & \text { United Kingdom } & 48 & \text { Barbados } & \\ 19 & \text { Italy } & 49 & \text { Belarus } & \\ 20 & \text { Portugal } & 50 & \text { Slovakia } & \\ 21 & \text { Spain } & 51 & \text { Switzerland } & \\ 22 & \text { Chile } & 52 & \text { Latvia } & \\ 23 & \text { Bahrain } & 53 & \text { Australia } & \\ 24 & \text { Qatar } & 54 & \text { Canada } & \\ 25 & \text { Poland } & 55 & \text { Serbia } & \end{array}$

Figure A1. List of countries included in the study.

\section{References}

1. Roser, M.; Ritchie, H. Maternal Mortality. Available online: https://ourworldindata.org/maternal-mortality (accessed on 6 October 2020).

2. World Health Organization. Maternal Mortality [Fact Sheet]. 2019. Available online: https://www.who.int/news-room/factsheets/detail/maternal-mortality (accessed on 5 October 2020).

3. World Bank. Maternal Mortality Ratio (Modeled Estimate, per 100,000 Live Births). 2015. Available online: https://data. worldbank.org/indicator/sh.sta.mmrt (accessed on 14 October 2020).

4. Say, L.; Chou, D.; Gemmill, A.; Tunçalp, Ö.; Moller, A.B.; Daniels, J.; Gülmezoglu, A.M.; Temmerman, M.; Alkema, L. Global causes of maternal death: A WHO systematic analysis. Lancet Glob. Health 2014, 2, e323-e333. [CrossRef]

5. Dumont, A.; Fournier, P.; Abrahamowicz, M.; Traoré, M.; Haddad, S.; Fraser, W.D. Quality of care, risk management, and technology in obstetrics to reduce hospital-based maternal mortality in Senegal and Mali (QUARITE): A cluster-randomised trial. Lancet 2013, 382, 146-157. [CrossRef]

6. Wong, P.C.; Kitsantas, P. A review of maternal mortality and quality of care in the USA. J. Matern.-Fetal Neonatal Med. 2020, 33, 3355-3367. [CrossRef] [PubMed] 
7. Geller, S.E.; Koch, A.R.; Garland, C.E.; MacDonald, E.J.; Storey, F.; Lawton, B. A global view of severe maternal morbidity: Moving beyond maternal mortality. Reprod. Health 2018, 15, 98. [CrossRef] [PubMed]

8. World Health Organization. Maternal Health: Overview. Available online: https://www.who.int/health-topics/maternalhealth\#tab=tab_1 (accessed on 7 October 2021).

9. Jennings, M.C.; Pradhan, S.; Schleiff, M.; Sacks, E.; Freeman, P.A.; Gupta, S.; Rassekh, B.M.; Perry, H.B. Comprehensive review of the evidence regarding the effectiveness of community-based primary health care in improving maternal, neonatal and child health: 2. maternal health findings. J. Glob. Health 2017, 7, 010902. [CrossRef]

10. Kumakech, E.; Anathan, J.; Udho, S.; Auma, A.G.; Atuhaire, I.; Nsubuga, A.G.; Ahaisibwe, B. Graduate Midwifery Education in Uganda Aiming to Improve Maternal and Newborn Health Outcomes. Ann. Glob. Health 2020, 86, 1-15. [CrossRef] [PubMed]

11. World Health Organization. Strategies toward Ending Preventable Maternal Mortality (EPMM); World Health Organization: Geneva, Switzerland, 2015.

12. International Confederation of Midwives. Global Standards for Midwifery Education; International Confederation of Midwives: The Hague, Netherlands, 2010.

13. World Health Organization Regional Office for the Western Pacific. Malaysia Health System Review; WHO Regional Office for the Western Pacific: Manila, Philippines, 2012.

14. Institute for Public Health. National Health and Morbidity Survey 2016: Maternal and Child Health (MCH), Volume Two: Maternal and Child Health Findings; Institute for Public Health: Kuala Lumpur, Malaysia, 2016.

15. Country Report: Malaysia. 2006. Available online: https://www.mhlw.go.jp/bunya/kokusaigyomu/asean/asean/kokusai/ siryou/dl/h18_malaysia1.pdf (accessed on 14 October 2020).

16. Ministry of Health Malaysia. Health Facts 2019, Reference Data for 2018; Ministry of Health Malaysia: Putrajaya, Malaysia, 2019.

17. Sindot, S. (Community Nurses in Malaysia). Personal communication, 2019.

18. Pathmanathan, I.; Liljestrand, J.; Martins, J.M.; Rajapaksa, L.C.; Lissner, C.; de Silva, A.; Selvaraju, S.; Singh, P.J. Investing in Maternal Health: Learning from Malaysia and Sri Lanka. Health, Nutrition, and Population; World Bank: Washington, DC, USA, 2003.

19. Ministry of Health Malaysia. Perinatal Care Manual, 3rd ed.; Ministry of Health Malaysia: Putrajaya, Malaysia, 2013.

20. Kaur, J.; Singh, H. Maternal Health in Malaysia: A Review. WebmedCentral Public Health 2011, 2, 1-19. [CrossRef]

21. Renfrew, M.J.; McFadden, A.; Bastos, M.H.; Campbell, J.; Channon, A.A.; Cheung, N.F.; Silva, D.R.A.D.; Downe, S.; Kennedy, H.P.; Malata, A. Midwifery and quality care: Findings from a new evidence-informed framework for maternal and newborn care. Lancet 2014, 384, 1129-1145. [CrossRef]

22. Tricco, A.C.; Langlois, E.V.; Straus, S.E. Rapid Reviews to Strengthen Health Policy and Systems: A Practical Guide; World Health Organization: Geneva, Switzerland, 2017.

23. Moher, D.; Liberati, A.; Tetzlaff, J.; Altman, D.G. Preferred reporting items for systematic reviews and meta-analyses: The PRISMA statement. BMJ 2009, 339, b2535. [CrossRef] [PubMed]

24. Shakirah, M.S.; Fun, W.H.; Kong, Y.L.; Anis-Syakira, J.; Balqis-Ali, N.Z.; Sindot, S.; Sararaks, S.; Shauki, N.I.A.A. Midwifery Qualification in Primary Care. 2019. Available online: https:/ / osf.io/gzn3a/ (accessed on 5 August 2021).

25. Alajaijian, S.; Ho, T. Optimizing the Identification of Grey Literature: A Rapid Review. Available online: https://www.peelregion. ca/health/library/pdf/rapid-reviews/optimizing-indentification-grey-literature.pdf (accessed on 7 October 2019).

26. Tyndall, J. AACODS Checklist. Available online: http://dspace.flinders.edu.au/jspui/handle/2328/3326 (accessed on 6 October 2020).

27. Nursing and Midwifery Board of Australia. Registration Standards. Available online: https://www.nursingmidwiferyboard.gov. au/registration-standards.aspx (accessed on 22 March 2019).

28. Australian Nursing and Midwifery Accreditation Council. Midwife Accreditation Standards 2014; Australian Nursing and Midwifery Accreditation Council: Canberra, Australia, 2014.

29. Nursing Midwifery Board of Ireland. Registration. Available online: https://www.nmbi.ie/Registration (accessed on 22 March 2019).

30. Nursing Midwifery Board of Ireland. Careers in Nursing and Midwifery: Where to Study to Become a Nurse or Midwife? Available online: https:/ / www.nmbi.ie/Careers-in-Nursing-Midwifery/Becoming-a-Nurse-Midwife/Where-to-study (accessed on 22 March 2019).

31. Nursing and Midwifery Council. Becoming a Midwife. Available online: https://www.nmc.org.uk/education/becoming-anurse-midwife-nursing-associate/becoming-a-midwife/ (accessed on 22 March 2020).

32. Singapore Nursing Board. Local Graduates. Available online: http://www.healthprofessionals.gov.sg/snb/registrationenrolment/application-for-registration-enrolment/local-graduates (accessed on 22 March 2019).

33. Midwifery Council of New Zealand. What Does It Take to Qualify as a Midwife? Available online: https://www. midwiferycouncil.health.nz/professional-standards/what-does-it-take-qualify-midwife (accessed on 22 March 2019).

34. Midwifery Council of New Zealand. Maintaining Competence. Available online: https://www.midwiferycouncil.health.nz/ midwives/maintaining-competence (accessed on 22 March 2019).

35. Midwifery Council of New Zealand. Becoming Registered to Practise. Available online: https://www.midwiferycouncil.health. nz/midwives/becoming-registered-practise (accessed on 22 March 2019).

36. Midwifery Education and Accreditation Council. Frequently Asked Questions (FAQ). Available online: http://meacschools.org/ education-faq/ (accessed on 4 March 2020). 
37. North American Registry of Midwives. How to Become a CPM. Available online: http://narm.org/certification/how-to-becomea-cpm/ (accessed on 22 March 2020).

38. Regulation on the Education, Rights and Obligations of Midwives and Criteria for Granting of Licences and Specialist Licences No. 1089/2012; Ministry of Welfare: Rekjavic, Iceland, 2012.

39. Act on Public Health Nurses, Midwives, and Nurses, Act No. 203 1948. Japan. Available online: http://www. japaneselawtranslation.go.jp / law /detail_main?id=2075\&re=02\&vm=02 (accessed on 14 October 2020).

40. Midwifery Act (Consolidated Text, OG 120/08, 145/10); The Croatian Parliament: Zagreb, Croatia, 2008.

41. Health Care Professions Act, Chapter 464; Ministry of Justice and Home Affairs: Valletta, Malta, 2003.

42. Nurses and Midwives Act Chapter 209, 2012 Revised Edition; The Law Revision Commission: Singapore, 2012.

43. Lebanese Order of Midwives. 2018. Available online: https://www.daleel-madani.org/civil-society-directory/lebanese-ordermidwives (accessed on 16 March 2019).

44. Law on Regulated Professions and Recognition of Professional Qualifications; Latvijas Vēstnesis: Riga, Latvia, 2001.

45. Nursing and Midwifery Profession Act B.E. 2528; Royal Thai Government Gazette: Bangkok, Thailand, 1985.

46. Chapter 194 Midwives Act; Renada. 2003. Available online: http://grenada.mylexisnexis.co.za/\# (accessed on 14 October 2020).

47. Nurses and Midwives Registration Act, Chapter 321, Revised Edition 2003; Law Revision Comissioner: Belmopan, Belize, 2003.

48. Medical Ordinance, Chapter 113; Blackhall Publishing: Pannipitiya, Sri Lanka, 2018.

49. Emons, J.K.; Luiten, M.I.J. Midwifery in Europe: An Inventory in fifteen EU-Member States; Deloitte \& Touche: Leusden, The Netherland, 2001.

50. Ruiz-Berdún, D. The competences of midwives in Spain over time. In Maternity Care in Different Countries. Midwife's Contribution, 1st ed.; Escuriet, R., Ed.; Consell de Collegis d'Infermeres i Infermers de Catalunya Rosselló: Barcelona, Spain, 2016 ; pp. 19-25.

51. Leon-Larios, F. The current situation of midwives in Spain. In Maternity Care in Different Countries. Midwife's Contribution, 1st ed.; Escuriet, R., Ed.; Consell de Collegis d'Infermeres i Infermers de Catalunya Rosselló: Barcelona, Spain, 2016; pp. 26-31.

52. Japanese Nursing Association. Midwifery in Japan; Japanese Nursing Association: Tokyo, Japan, 2018.

53. Beeckman, K.; Reyns, M. Midwifery in Belgium. In Maternity Care in Different Countries. Midwife's Contribution, 1st ed.; Escuriet, R., Ed.; Consell de Collegis d'Infermeres i Infermers de Catalunya Rosselló: Barcelona, Spain, 2016.

54. Daly, D. The maternity services and becoming a midwife in Ireland. In Maternity Care in Different Countries. Midwife's Contribution, 1st ed.; Escuriet, R., Ed.; Consell de Collegis d'Infermeres i Infermers de Catalunya Rosselló: Barcelona, Spain, 2016.

55. Gasser, L.; Daly, D.; Benoit Truong Canh, M. The Profession of Midwives in Croatia. Available online: http://www.hupp.hr/ baza/upload/File/midwife\%20report1_eng.pdf (accessed on 22 March 2019).

56. Sahakyan, S.; Aslanyan, L.; Hovhannisyan, S.; Poghosyan, K.; Petrosyan, V. An Evaluation of Midwifery Education System in Armenia. Armenia: American University of Armenia. Available online: https:/ / chsr.aua.am/files/2019/03/An-Evaluation-ofMidwifery-Education-System-in-Armenia_2019.pdf (accessed on 22 March 2019).

57. Western Pacific Region Nursing and Midwifery Databank. Country: Fiji. Available online: http://www.wpro.who.int/hrh/ about/nursing_midwifery/db_fiji_2013.pdf (accessed on 22 March 2019).

58. Atkin, L.C.; Keith-Brown, K.; Rees, M.W.; Sesia, P. Midwifery in Mexico; Management Sciences for Health: Medford, MA, USA, 2016.

59. Public Interest Incorporated Foundation. Japan Society of Midwifery Education. Available online: http://www.zenjomid.org/ img/2015icm.pdf (accessed on 22 March 2019).

60. Australian College of Midwives. FAQ-Is Midwifery for Me? Available online: https://www.midwives.org.au/faq-midwifery-me (accessed on 22 March 2019).

61. The Royal College of Midwives. How to Become a Midwife? Available online: https://www.rcm.org.uk/learning-and-career/ becoming-a-midwife (accessed on 22 March 2020).

62. New Zealand College of Midwives. Regulation. Available online: https://www.midwife.org.nz/midwives/midwifery-in-newzealand/regulation/ (accessed on 22 March 2019).

63. American College of Nurse-Midwives. Definition of Midwifery and Scope of Practice of Certified Nurse-Midwives and Certified Midwives. Available online: https:/ / www.midwife.org/acnm/files/ACNMLibraryData/UPLOADFILENAME/0000000002 66/Definition\%20of\%20Midwifery\%20and\%20Scope \%20of\%20Practice\%20of\%20CNMs\%20and\%20CMs\%20Feb\%202012.pdf (accessed on 22 March 2020).

64. American College of Nurse-Midwives. Information for Midwives Educated Abroad. Available online: http://www.midwife.org/ Foreign-Educated-Nurse-Midwives (accessed on 22 March 2020).

65. American College of Nurse-Midwives. Comparison of Certified Nurse-Midwives, Certified Midwives, Certified Professional Midwives Clarifying the Distinctions Among Professional Midwifery Credentials in the US. Available online: http://www. midwife.org/acnm/files/ccLibraryFiles / FILENAME/000000006807/FINAL-ComparisonChart-Oct2017.pdf (accessed on 22 March 2020).

66. American College of Nurse-Midwives. Become a Midwife. Available online: http://www.midwife.org/Become-a-Midwife (accessed on 22 March 2020).

67. Urbánková, E.; Hospodková, P.; Severová, L. The Assessment of the Quality of Human Resources in the Midwife Profession in the Healthcare Sector of the Czech Republic. Economies 2018, 6, 38. [CrossRef]

68. Natan, M.B.; Ehrenfeld, M. Nursing and midwifery education, practice, and issues in Israel. Nurs. Health Sci. 2011, 13, 1-3. [CrossRef] [PubMed] 
69. Mattern, E.; Lohmann, S.; Ayerle, G.M. Experiences and wishes of women regarding systemic aspects of midwifery care in Germany: A qualitative study with focus groups. BMC Pregnancy Childbirth 2017, 17, 389. [CrossRef] [PubMed]

70. Mivšek, P.; Pahor, M.; Hlebec, V.; Hundley, V. How do midwives in Slovenia view their professional status? Midwifery 2015, 31, 1193-1201. [CrossRef]

71. Lee, K.H. Improving the standards of midwifery education and practice and extending the role of a midwife in Korean women and children's health care. J. Korean Acad. Nurs. 2003, 33, 1111-1118. [CrossRef] [PubMed]

72. Lillo, E.; Oyarzo, S.; Carroza, J.; Román, A. Midwifery in Chile, A Successful Experience to Improve Women's Sexual and Reproductive Health: Facilitators \& Challenges. J. Asian Midwives 2016, 3, 63-69.

73. Boyer, D. Midwifery in Northern Belize. J. Midwifery Womens Health 2001, 46, 33-39. [CrossRef]

74. Federal Public Service (FPS) Health, Food Chain Safety and Environment. Regulated Healthcare Professions in Belgium. Available online: https: / / www.health.belgium.be/en/health/taking-care-yourself/patient-related-themes/cross-border-health-care/ healthcare-providers-0 (accessed on 22 March 2019).

75. Ministry of Health. Licence for Independent Practice of Nursing and Midwifery. Available online: http://eugo.gov.si/en/ permits/permit/12580/showPermit/ (accessed on 7 March 2019).

76. Ministry of Health. Entry in the Register of Nursing and Midwifery Services. Available online: http:/ / eugo.gov.si/en/permits/ permit/12579/showPermit/ (accessed on 22 March 2019).

77. Ministry of Public Health. Healthcare Practitioners Registration \& Licensing. Available online: https://www.moph.gov.qa/ health-services/Pages/healthcare-practitioners-registration-n-licensing.aspx (accessed on 22 March 2019).

78. Ministry of Public Health. Information about the Qatar Council for Healthcare Practitioners (QCHP). Available online: https: //www.prometric.com/test-takers/search/schq2aspx (accessed on 22 March 2019).

79. Ministry of Health Government of Grenada. Careers in Nursing: Midwifery. Available online: http://www.health.gov.gd/index. php?option=com_content\&view=article\&id=189\&Itemid=486\&lang=en (accessed on 7 March 2019).

80. Federal Public Service (FPS) Health, Food Chain Safety and Environment. Healthcare Providers. Available online: https://www. health.belgium.be/en/health/taking-care-yourself/patient-related-themes/cross-border-health-care/healthcare-providers (accessed on 22 March 2019).

81. UAE Nursing and Midwifery Council. UAE Nursing and Midwifery Education Standards; UAE Nursing and Midwifery Council: Dubai, United Arab Emirates, 2013.

82. Nursing and Midwifery Board of Ireland. Requirements and Standards for the Midwife Registration Education Programme, 3rd ed.; Nursing and Midwifery Board of Ireland: Dublin, Ireland, 2005; Available online: https://www.nmbi.ie/nmbi/media/ NMBI/Requirements-and-Standards-for-the-Midwife-Registration-Education-Programme-3rd-ed.pdf?ext=.pdf (accessed on 22 March 2019).

83. Nursing Midwifery Board of Ireland. Midwife Post-RGN Registration: Standards and Requirements. Available online: https: //www.nmbi.ie/Education/Standards-and-Requirements/Midwife-Post-RGN (accessed on 22 March 2019).

84. Nursing and Midwifery Council. Standards for Competence for Registered Midwives; Nursing and Midwifery Council: London, UK, 2020.

85. National Health Regulatory Authority. Healthcare Professional Licensing Standards: Nurses 2017. Available online: http:/ / www.nhra.bh/MediaHandler/GenericHandler/documents/departments/HCP/Qualifications_Requirements/HCP_ Standards_Licensing\%20requirements\%20for\%20nurses_v1.0_2017.pdf (accessed on 22 March 2019).

86. Weiss, S.; Ditto, M.; Füszl, S.; Lanske, P.; Lust, A.; Oberleitner-Tschan, C.; Wenda, S. Healthcare Professions in Austria. Available online: https:/ / www.sozialministerium.at/siteEN/Health/Healthcare_Professions / Brochure_Healthcare_Professions_in_Austria (accessed on 5 March 2019).

87. Beňušová, K.; Hozlárová, M.; Mend'anová, Z.; Nagy, M.; Slezáková, Z.; Šablová, V.; Závodná, V. Education of Healthcare Professionals in the Slovak Republic; Ministry of Health of the Slovak Republic: Bratislava, Slovakia, 2006.

88. Qatar Council for Health Practitioners. Nursing Regulations in the State of Qatar. Available online: http://www.qchp.org.qa/ en/Documents /Nursing\%20Regulations\%20in\%20the\%20State\%20of\%20Qatar.pdf (accessed on 22 March 2019).

89. Qatar Council of Health Practitioners. Circular No. (12/2016). Available online: http://www.qchp.org.qa/en/QCHPCirculars/ Circular\%20(12-2016)\%20-\%20Eng.pdf (accessed on 22 March 2019).

90. Jahlan, I. Perspectives on Birthing Services in Saudi Arabia; Monash University: Melbourne, Australia, 2016.

91. Zondag, L.; Cadée, F.; de Geus, M. Midwifery in Netherlands. Available online: https://www.knov.nl/serve/file/knov.nl/knov_ downloads/526/file/Midwifery_in_The_Netherlands_versie_2017.pdf (accessed on 22 March 2019).

92. Ministry of Health Malaysia. Human Resources for Health, Country Profiles 2015 Malaysia; Planning Division, Ministry of Health Malaysia: Putrajaya, Malaysia, 2016; p. 52.

93. Kruk, M.E.; Gage, A.D.; Arsenault, C.; Jordan, K.; Leslie, H.H.; Roder-DeWan, S.; Adeyi, O.; Barker, P.; Daelmans, B.; Doubova, S.V.; et al. High-quality health systems in the Sustainable Development Goals era: Time for a revolution. Lancet Glob. Health 2018, 6, e1196-e1252. [CrossRef]

94. World Health Organization. Strengthening Quality Midwifery Education for Universal Health Coverage 2030: Framework for Action; World Health Organization: Geneva, Switzerland, 2019.

95. Francis, K.; Birks, M.; Al-Motlaq, M.; Davis, J.; Miles, M.; Bailey, C. Responding to a rural health workforce shortfall: Double degree preparation of the nurse midwife. Aust. J. Rural Health 2010, 18, 210-211. [CrossRef] 
96. Gottfreðsdóttir, H.; Nieuwenhuijze, M.J. Midwifery education: Challenges for the future in a dynamic environment. Midwifery 2018, 59, 78-80. [CrossRef] [PubMed]

97. American Association of Colleges of Nursing. Fact Sheet: The Impact of Education on Nursing Practice; American Association of Colleges of Nursing: Washington, DC, USA, 2019.

98. Johnson, J.H. Differences in the performances of baccalaureate, associate degree, and diploma nurses: A meta-analysis. Res. Nurs. Health 1988, 11, 183-197. [CrossRef]

99. Aiken, L.H.; Sloane, D.M.; Bruyneel, L.; Van den Heede, K.; Griffiths, P.; Busse, R.; Diomidous, M.; Kinnunen, J.; Kózka, M.; Lesaffre, E. Nurse staffing and education and hospital mortality in nine European countries: A retrospective observational study. Lancet 2014, 383, 1824-1830. [CrossRef]

100. Cho, E.; Sloane, D.M.; Kim, E.-Y.; Kim, S.; Choi, M.; Yoo, I.Y.; Lee, H.S.; Aiken, L.H. Effects of nurse staffing, work environments, and education on patient mortality: An observational study. Int. J. Nurs. Stud. 2015, 52, 535-542. [CrossRef]

101. Estabrooks, C.A.; Midodzi, W.K.; Cummings, G.G.; Ricker, K.L.; Giovannetti, P. The impact of hospital nursing characteristics on 30-day mortality. Nurs. Res. 2005, 54, 74-84. [CrossRef] [PubMed]

102. Kutney-Lee, A.; Sloane, D.M.; Aiken, L.H. An increase in the number of nurses with baccalaureate degrees is linked to lower rates of postsurgery mortality. Health Aff. 2013, 32, 579-586. [CrossRef] [PubMed]

103. Romp, C.R.; Kiehl, E.M.; Bickett, A.; Bledsoe, S.F.; Brown, D.S.; Eitel, S.B.; Wall, M.P. Motivators and barriers to returning to school: RN to BSN. J. Nurses Prof. Dev. 2014, 30, 83-86. [CrossRef] [PubMed]

104. Finch, D.J. Degree-level education is an essential part of modern health care. Nurs. Stand. 2016, 30, 28. [CrossRef]

105. Swindells, C.; Willmott, S. Degree vs diploma education: Increased value to practice. Br. J. Nurs. 2003, 12, 1096-1104. [CrossRef]

106. Shin, K.R. Critical thinking ability and clinical decision-making skills among senior nursing students in associate and baccalaureate programmes in Korea. J. Adv. Nurs. 1998, 27, 414-418. [CrossRef]

107. Muoni, T. Decision-making, intuition, and the midwife: Understanding heuristics. Br. J. Midwifery 2012, 20, 52-56. [CrossRef]

108. Lee, D.S.; Abdullah, K.L.; Subramanian, P.; Bachmann, R.T.; Ong, S.L. An integrated review of the correlation between critical thinking ability and clinical decision-making in nursing. J. Clin. Nurs. 2017, 26, 4065-4079. [CrossRef] [PubMed]

109. You, L.-M.; Aiken, L.H.; Sloane, D.M.; Liu, K.; He, G.-P.; Hu, Y.; Jiang, X.-L.; Li, X.-H.; Li, X.-M.; Liu, H.-P. Hospital nursing, care quality, and patient satisfaction: Cross-sectional surveys of nurses and patients in hospitals in China and Europe. Int. J. Nurs. Stud. 2013, 50, 154-161. [CrossRef] [PubMed]

110. U.S. Department of Health and Human Services. The U.S. Nursing Workforce: Trends in Supply and Education; U.S. Department of Health and Human Services: Washington, DC, USA, 2013.

111. Roets, L.; Botma, Y.; Grobler, C. Scholarship in nursing: Degree-prepared nurses versus diploma-prepared nurses. Health $S A$ Gesondheid 2016, 21, 422-430. [CrossRef]

112. Sackett, D.L.; Rosenberg, W.M.; Gray, J.M.; Haynes, R.B.; Richardson, W.S. Evidence based medicine: What it is and what it isn't. BMJ 1996, 312, 71-72. [CrossRef]

113. World Health Organization. Facilitating Evidence-Based Practice in Nursing and Midwifery in the WHO European Region; World Health Organization Regional Office for Europe: Copenhagen, Denmark, 2017.

114. De Leo, A.; Bayes, S.; Geraghty, S.; Butt, J. Midwives' use of best available evidence in practice: An integrative review. J. Clin. Nurs. 2019, 28, 4225-4235. [CrossRef] [PubMed]

115. Lai, N.M.; Teng, C.L.; Lee, M.L. The place and barriers of evidence based practice: Knowledge and perceptions of medical, nursing and allied health practitioners in Malaysia. BMC Res. Notes 2010, 3, 279. [CrossRef]

116. Homer, C.S.; Friberg, I.K.; Dias, M.A.B.; ten Hoope-Bender, P.; Sandall, J.; Speciale, A.M.; Bartlett, L.A. The projected effect of scaling up midwifery. Lancet 2014, 384, 1146-1157. [CrossRef]

117. Srisawad, K. Role of Midwife in Preconception Care. Songklanagarind J. Nurs. 2017, 37, 157-165.

118. Hussein, N.; Kai, J.; Qureshi, N. The effects of preconception interventions on improving reproductive health and pregnancy outcomes in primary care: A systematic review. Eur. J. Gen. Pract. 2016, 22, 42-52. [CrossRef]

119. Yngyknd, S.G.; Mohammad-Alizadeh-Charandabi, S.; Babapour, J.; Mirghafourvand, M. The effect of counselling on preconception lifestyle and awareness in Iranian women contemplating pregnancy: A randomized control trial. J. Matern.-Fetal Neonatal Med. 2018, 31, 2538-2544. [CrossRef] [PubMed]

120. Suruhanjaya Perkhidmatan Awam Malaysia. Jururawat Masyarakat Gred U19. 2020. Available online: https:/ /www.spa.gov. my/spa/laman-utama/gaji-syarat-lantikan-deskripsi-tugas/spm-svm-skm-sijil/jururawat-masyarakat-gred-u19 (accessed on 10 July 2020).

121. Midwives Act 1966 (Amended 2006); The Commissioner of Law Revision, Malaysia: Kuala Lumpur, Malaysia, 2006.

122. Rooney, A.; van Ostenberg, P. Licensure, Accreditation, and Certification: Approaches to Health Services Quality; Centre for Human Services: Bethesda, MD, USA, 1999.

123. Wade, C.H. Perceived effects of specialty nurse certification: A review of the literature. AORN J. 2009, 89, 183-192. [CrossRef] [PubMed]

124. Cary, A.H. Certified registered nurses: Results of the study of the certified workforce. Am. J. Nurs. 2001, 101, 44-52. [CrossRef]

125. Boyle, D.K.; Cramer, E.; Potter, C.; Gatua, M.W.; Stobinski, J.X. The relationship between direct-care RN specialty certification and surgical patient outcomes. AORN J. 2014, 100, 511-528. [CrossRef] [PubMed]

126. Sutherland, K.; Leatherman, S. Does certification improve medical standards? BMJ 2006, 333, 439-441. [CrossRef] [PubMed] 
127. Bradshaw, C.; Tighe, S.M.; Doody, O. Midwifery students' experiences of their clinical internship: A qualitative descriptive study. Nurse Educ. Today 2018, 68, 213-217. [CrossRef]

128. Lukasse, M.; Henriksen, L. Norwegian midwives' perceptions of their practice environment: A mixed methods study. Nurs. Open 2019, 6, 1559-1570. [CrossRef]

129. Schytt, E.; Waldenström, U. How well does midwifery education prepare for clinical practice? Exploring the views of Swedish students, midwives and obstetricians. Midwifery 2013, 29, 102-109. [CrossRef]

130. Hughes, A.J.; Fraser, D.M. 'Sink or swim': The experience of newly qualified midwives in England. Midwifery 2011, 27, 382-386. [CrossRef]

131. van der Putten, D. The lived experience of newly qualified midwives: A qualitative study. Br. J. Midwifery 2008, 16, 348-358. [CrossRef]

132. Hobbs, J.; Green, S. Development of a preceptorship programme. Br. J. Midwifery 2003, 11, 372-375. [CrossRef]

133. Enrico, N.B. The lived experiences of mentoring nurses in Malaysia. Nurse Media J. Nurs. 2011, 1, 87-104. [CrossRef]

134. Pairman, S.; Dixon, L.; Tumilty, E.; Gray, E.; Campbell, N.; Calvert, S.; Kensington, M. The Midwifery First Year of Practice programme: Supporting New Zealand midwifery graduates in their transition to practice. N. Z. Coll. Midwives J. 2016, 52, 12-19. [CrossRef]

135. Dixon, L.; Calvert, S.; Tumilty, E.; Kensington, M.; Gray, E.; Lennox, S.; Campbell, N.; Pairman, S. Supporting New Zealand graduate midwives to stay in the profession: An evaluation of the Midwifery First Year of Practice programme. Midwifery 2015, 31, 633-639. [CrossRef]

136. Yazıc1, S. Midwifery students' demographic characteristics and the effect of clinical education on preparation for professional life in Turkey. Nurse Educ. Pract. 2010, 10, 367-373. [CrossRef] [PubMed] 